\title{
Phonological Errors in Pronouncing Basa Osing: Analysis of Language Behavior
}

\author{
Ressi Maulidina Delijar \\ Magister of Linguistics, Faculty of Cultural Studies, Universitas Brawijaya, Indonesia \\ ressimdelijar@gmail.com
}

\begin{abstract}
Article Info
Article History

- Article Received $05^{\text {th }}$ July 2019

- Article Reviewed $25^{\text {th }}$ September 2019

- Article Accepted $04^{\text {th }}$ October 2019

Keywords

Language Behavior

Phonological Errors

Basa Osing

Banyuwangi

\section{ABSTRACT}

This research aims to determine the language behavior of Basa Osing speakers in phonological aspects. This research is important because of the debate over the Basa Osing linguistic status which considers that Basa Osing is only a variation of Javanese, and the other assumption that Basa Osing is an independent local language. This kind of situation will probably affect the behavior of Basa Osing speakers. This research used qualitative methods and collecting data by using silent movie and picture. The participants involved in this research are 10 Basa Osing speakers. Errors found in pronouncing Basa Osing are in form of ignoring the diphtongization of vocals $/ \mathrm{i} /$ and $/ \mathrm{u} /$ at the end of the word and the palatalization of /b/ at the beginning and at the middle of the word, /d/ at the middle of the word, /D/ at the middle of the word, /g/ at the beginning and middle of the word, and $/ \mathrm{m} /$ in the middle of the word, so that the spoken word sounds more like a word in Javanese than Basa Osing.
\end{abstract}

\section{INTRODUCTION}

Basa Osing is a local language originally from Banyuwangi. Banyuwangi is one of district in East Java. Basa Osing, even up to now, its linguistic status is still debated. Some people claim that Basa Osing is an independent language, but some people claim that Basa Osing is only "part" or variation of other local languages.

But, in 1990 at Kongres Bahasa Jawa II in Batu, Basa Osing declared itself as an independent local language and introduced itself not as a variation of Javanese. Therefore, Basa Osing as a local language was taught in school as local content[1].

However, in 2014, the Governor of East Java removed Basa Osing as local content in East Java, so that the local language taught was only Javanese and Madurese. This is written in East Java Governor Regulation No. 19 of 2014[2]. The elimination of Basa Osing from the local content curriculum was because Basa Osing is considered as Javanese in different "accent" and does not have a standard grammar. With this kind of situation, Basa Osing might be forgotten increasingly in the future. Then, it can probably affect the language behavior of its speakers.

This study wants to find out the current language behavior of Basa Osing speakers in phonological aspect. Because what makes Basa Osing is different to Javanese, is clearly shown in their phonological aspect. More detail about differences between Basa Osing and Javanese are explained in literature review.

\section{II.LITERATURE REVIEW}

\section{a. Differences between Basa Osing and Javanese}

Many people thought that Basa Osing and Javanese are very similar, but some contrast shown linguistically between Basa Osing and Javanese is their phonological aspect.

1. Basa Osing has seven vowel phonemes, /a/, /i/, /u/, /e/, /o/, /o/, and /o/. But phonemes /i/ and $/ \mathrm{u} /$ in open ultima syllables become [ai] dan [au], 
Delijar, Ressi Maulidina. Phonological Errors in Pronouncing Basa Osing: Analysis of Language Behavior

phonemes /i/ and /u/ in close ultima syllables become $[\varepsilon]$ and $[0][3]$.

2. The consonant group pronunciation of $/ \mathrm{w}, \mathrm{j}, \mathrm{r}, \mathrm{l} / \mathrm{is}$ always suppressed so that it sounds /ww, ji, rr, ll/. Other than that, the consonant group pronunciations of / b, w, g, d, j, l / often experience palatalization so that it sounds $\left[\mathrm{b}^{\mathrm{y}}, \mathrm{w}^{\mathrm{y}}, \mathrm{g}^{\mathrm{y}}, \mathrm{d}^{\mathrm{y}}, \mathrm{l}^{\mathrm{y}}\right][3]$

To explain more in detail, here are the table of consonants in Basa Osing (taken from Kamus Bahasa Daerah Using - Indonesia) [4].

\begin{tabular}{|c|c|c|c|c|}
\hline \multirow[t]{2}{*}{ Phonemes } & \multirow[t]{2}{*}{ Allophones } & \multicolumn{3}{|c|}{ Example/Position in Words } \\
\hline & & Beginning & Middle & End \\
\hline \multirow[t]{4}{*}{$/ \mathrm{b} /$} & [b] & Bentuk & Ambi & Gubab \\
\hline & [by] & 'lempar' & 'dengan' & 'bohong' \\
\hline & & Bakal & Jebèng & \\
\hline & & 'tunangan' & 'anak pr.' & \\
\hline \multirow[t]{5}{*}{ /d/ } & [d] & $D u d u$ & Wadon & Koled \\
\hline & [dy] & 'bukan' & 'perempuan' & 'lama' \\
\hline & & Damèn & Rèndèn & - \\
\hline & & 'jerami’ & 'daun & \\
\hline & & & pisang' & \\
\hline \multirow[t]{4}{*}{ /D/ } & {$[\mathrm{D}]$} & Dbuwnur & Pudhot & - \\
\hline & Dy $]$ & 'tinggi' & 'duda' & - \\
\hline & & Dhawnk. & Gedhèg & \\
\hline & & 'kelabu’ & 'dinding' & \\
\hline \multirow[t]{4}{*}{ /g/ } & {$[\mathrm{g}]$} & Geneng & Sugeng & Bojog \\
\hline & {$\left[\mathrm{g}^{\mathrm{y}}\right]$} & 'biar' & 'angkub' & 'kera' \\
\hline & & Ganas & Legèn 'nira' & \\
\hline & & 'boros' & & \\
\hline \multirow[t]{4}{*}{$/ d_{3} /$} & {$[\mathrm{d}]$} & Jugil & Rijig & - \\
\hline & {$[\mathrm{d} 3 \mathrm{y}]$} & 'dengki' & 'bersib' & - \\
\hline & & Jarit 'kain' & Lèjèg & \\
\hline & & & 'becek' & \\
\hline \multirow[t]{3}{*}{ /1/ } & [1] & Lendhu & Kiling & Kapal \\
\hline & {$[\mathrm{ly}]$} & 'lamban' & 'titiran' & 'kuda' \\
\hline & & Lab 'nab' & Kilèn 'kiri' & - \\
\hline \multirow[t]{4}{*}{$/ \mathrm{m} /$} & {$[\mathrm{m}]$} & Magib & Lumur & Inum \\
\hline & {$\left[\mathrm{m}^{\mathrm{y}}\right]$} & 'masib' & 'gelas' & 'minum' \\
\hline & & Makenè & Sumèb & - \\
\hline & & 'biar' & 'ramab' & \\
\hline \multirow[t]{4}{*}{$/ \mathrm{n} /$} & [n] & Nawi & Randhu & Sengkan \\
\hline & {$[\mathrm{ny}]$} & 'barangkali' & 'nanti' & 'tanjakan' \\
\hline & & - & Sunar & - \\
\hline & & & 'sinar' & \\
\hline \multirow[t]{3}{*}{$/ \mathrm{y} /$} & [y] & Ngethèl & Tingkes & Jajang \\
\hline & {$\left[\mathrm{g}^{\mathrm{y}}\right]$} & 'terbiasa' & 'ikat' & 'bambu' \\
\hline & & - & Bengen & . \\
\hline \multirow[t]{5}{*}{$/ \mathbf{n} /$} & {$[\mathrm{n}]$} & Nyak & Unyik & - \\
\hline & {$[\mathrm{ny}]$} & 'terimalah' & 'tawa' & - \\
\hline & & Nyang 'ke' & Genyèh & \\
\hline & & & "busuk & \\
\hline & & & berair' & \\
\hline
\end{tabular}

\begin{tabular}{|c|c|c|c|c|}
\hline$/ \mathrm{r} /$ & $\begin{array}{c}{[\mathrm{r}]} \\
{\left[\mathrm{r}^{\mathrm{y}}\right]}\end{array}$ & $\begin{array}{l}\text { Rada } \\
\text { 'agak' } \\
\text { - }\end{array}$ & $\begin{array}{c}\text { Aran } \\
\text { 'nama' } \\
\text { Iras 'serong' }\end{array}$ & $\begin{array}{l}\text { Menur } \\
\text { 'melati' } \\
\text { - }\end{array}$ \\
\hline$/ \mathrm{w} /$ & $\begin{array}{c}{[\mathrm{w}]} \\
{[\mathrm{w}]}\end{array}$ & $\begin{array}{l}\text { Warah } \\
\text { 'beritabu' } \\
\text { Wak } \\
\text { 'uwak' }\end{array}$ & $\begin{array}{l}\text { Junut } \\
\text { 'ambil' } \\
\text { Tuwète } \\
\text { 'tua' }\end{array}$ & - \\
\hline
\end{tabular}

Table 1. Consonants in Basa Osing

With the same language root, and contact with Javanese through its speakers, many Javanese and Basa Osing words are[5] :

1) the same pronunciation but different meanings for example:

\begin{tabular}{ccc}
\hline Words & $\begin{array}{c}\text { Meaning in } \\
\text { Basa Osing }\end{array}$ & $\begin{array}{c}\text { Meaning in } \\
\text { Javanese }\end{array}$ \\
\hline kadhung & 'if & 'too late' \\
\hline rabi & 'wife' & 'to marry' \\
\hline sugeng & 'arrogant' & $\begin{array}{c}\text { to greet } \\
\text { people, for } \\
\text { example } \\
\text { "sugeng Dalu" } \\
\text { means good } \\
\text { evening. }\end{array}$ \\
\hline tembung & 'ball' & 'word' \\
\hline & Table 2. Example 1 &
\end{tabular}

2) similar in pronunciation and exactly the same meaning for example:

\begin{tabular}{ccc}
\hline Basa Osing & Javanese & Meaning \\
\hline ambi & ambek & 'with' \\
\hline bengen & biyen & 'formerly' \\
\hline juwut & jumuk & 'take' \\
\hline lobok & lombok & 'chili' \\
\hline & Table 3. Example 2 &
\end{tabular}

3) both the same usage and meaning, but Basa Osing already has its own equivalent words for example:

\begin{tabular}{ccc}
\hline $\begin{array}{c}\text { Original } \\
\text { Basa Osing }\end{array}$ & Javanese** & Meaning \\
\hline gadug & teka & 'to arrive' \\
\hline elom & luwe & 'hungry' \\
\hline parek & cidhek & 'close to' \\
\hline raina & awan & 'noon' \\
\hline & Table 4. Example 3 &
\end{tabular}

**) these words are still understandable and sometimes used in Basa Osing.

\section{b. Language Behavior}

Language behavior according to Kridalaksana[6], is a concept that is equated with performance, and different from competence. Language behavior is defined as the real output of linguistic and nonlinguistic, in terms of linguistics can be in the form of certain utterances, including also grammatical errors. Whereas in terms of non-linguistic, language behavior 
can be influenced by psychological factors that accompany the use of language. There are misconceptions about language behavior and language attitude. According to Ramadani et al[7], language attitude is how to think, to use, and to feel the language. The same concept also stated by Gusnawaty[8], language attitude is a mental position or feeling towards someone's own language or someone else's language.

The relationship between language attitude and language behavior is often debated, some researchers claim that behavior is always a reflection of attitude, while some others state that behavior is not always a reflection of attitude.

\section{METHODOLOGY}

Qualitative method is used to investigate the language behavior Basa Osing speakers. Therefore, to investigate their behavior, observation to participants' utterances by using silent movie and picture was applied.

This research used convenience sampling technique. Convenience sampling model used in this research was volunteer sampling. Convenience sampling was used to draw participants that are both easily accessible and willing to participate in this research.

\section{a. Participants}

The participants involved were 10 people. Participants involved were those who were willing to take the process of retrieving speech data to be recorded and analyzed. The 10 participants are:

\begin{tabular}{|c|c|c|c|}
\hline No. & Participant & Village & Occupation \\
\hline 1. & $\begin{array}{l}\text { RS (17, } \\
\text { Female) }\end{array}$ & Singotrunan & Student \\
\hline 2. & $\begin{array}{l}\text { DF (17, } \\
\text { Male) }\end{array}$ & Singotrunan & Student \\
\hline 3. & Z (18, Male) & Karangrejo & Student \\
\hline 4. & $\begin{array}{l}\text { LD (24, } \\
\text { Male) }\end{array}$ & Penganjuran & Civil Servant \\
\hline 5. & $\begin{array}{l}\text { RA (23, } \\
\text { Female) }\end{array}$ & Panderejo & $\begin{array}{l}\text { Graduate } \\
\text { Program } \\
\text { Student }\end{array}$ \\
\hline 6. & $\begin{array}{l}\text { SY (26, } \\
\text { Female) }\end{array}$ & Sobo & Banker \\
\hline 7. & B (28, Male) & Kepatihan & Entrepreneur \\
\hline 8. & $\begin{array}{l}\text { WR (53, } \\
\text { Male) }\end{array}$ & Singotrunan & Teacher \\
\hline 9. & $\begin{array}{l}\text { WW (55, } \\
\text { Female) }\end{array}$ & Sobo & Banker \\
\hline
\end{tabular}

10. $\begin{gathered}\text { Y (51, Kepatihan } \\ \text { Female })\end{gathered}$ Housewife

Table 5. List of Participants

\section{b. Data Collection}

The researcher asked the participants to retell a silent movie and a picture in Basa Osing. This step is adapted from Sukamto and Purwo[9]. The utterances of participants were recorded as data to know their behavior in speaking Basa Osing and to know their proficiencies as well. The silent movie used in this research was taken from one of Indonesian commercial (40 seconds). Commercial was chosen because commercial has a message that can be easily understood by the audience from all range of age. Then, for the picture used was the picture of traditional market consist of many people doing various activities. These instruments were used to trigger the participants to speak Basa Osing spontaneously in the same topics. The usage of two kinds of instruments was necessary in order to gain more utterances and data. The utterances from the participants were recorded and analyzed to see the pattern and their behavior while using Basa Osing.

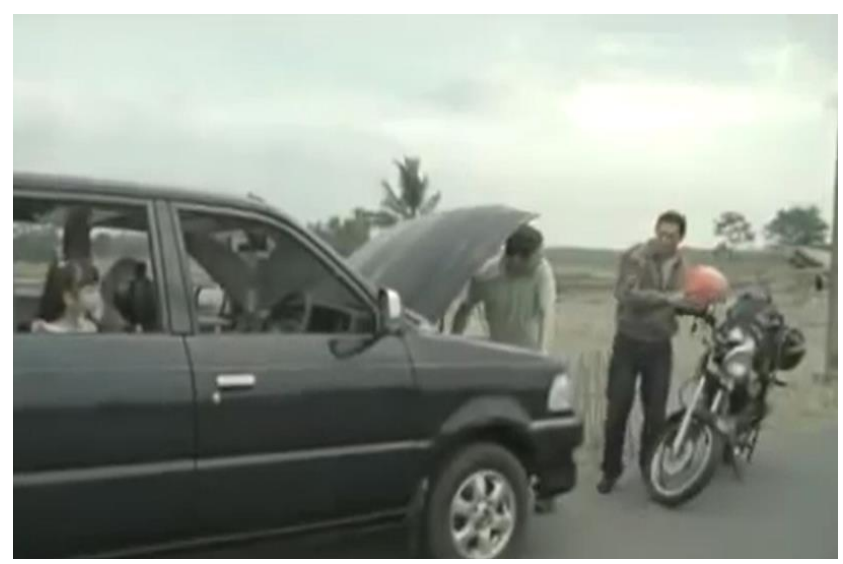

Picture 1. Screen Capture of Silent Movie Used Source: https://www.youtube.com/watch?v=eAKOPfGxH9Q

\section{c. Data Analysis}

1. The data was obtained by recording the participants' utterance in Basa Osing from given silent movie and picture. The researcher asked the participants to retell what was inside the movie and picture.

2. Listening and transcribing carefully the utterances from the recorder. 
3. Analyzing the utterances of each participant and comparing each other to see their characteristics or pattern in speaking and their behavior.

\section{RESULT AND DISCUSSION}

Based on the results, the prominent behavior is from the behavior of pronuncing consonants and vocals correctly.

1. Participants do not have any knowledge of any consonants used in Basa Osing. This is proved by almost all participants in this group that were pronuncing consonants $\mathbf{f}$ and $\mathbf{v}$ (both spoken /f/) in retelling silent movie and picture.

"Ning video iku, ndelokna ana uwong (emmm) mudik." (RS, 17)

"Ning video iku, (emmmm), nyeritakna unong mbantu uwong susah.." (DF, 17)

"Ning foto iki, ning gambar iki, (emmm) ana tempaté nang pasar" (DF, 17)

"Ndék video iku mau, nyeritakna unong hang susah." $(\mathrm{Z}, 18)$

"Dadi ceritané teka video iku mau ana bapak-bapak. byalek teka kerja" (LD, 24)

From the cited data above, it can be seen that participants did not realize that the use of consonants $\mathbf{f}$ and $\mathbf{v}$ (both spoken /f/) is something that should not be done in Basa Osing, because those consonants do not exist in Basa Osing. Basa Osing itself absorbs new vocabulary or words from other languages by changing consonants /f/ or / $/$ to $/ \mathrm{p} /$. It seems that, this is the only participant who realized to use the consonant $/ \mathrm{p} /$ to pronounce the word video.

"Dadi nang pidio [piDiyo] ikau ana lare lanang bang numpak sepeda motor" (RA, 23)

Although it is still acceptable and understandable if a speaker uses consonant /f/ rather than /p/, but it shows unfavorable language behavior.

2. Participants also do not have awareness of vocal sounds such as $[\mathrm{A}]$ and $[\mathrm{I}]$ in some Basa Osing words, as a result the participant sounds like using an Indonesian word. According to the Kamus Bahasa Using[4], [A] is an allophone or sound variation of $/ \mathrm{a} /$, while [] is an allophone of /i/. For example:

"Tapi tepak ana anaké metu, dikei boneka garagara iling anaké nang omah.” (Z, 18)

Z (18) pronounced the word gara-gara 'cause' with [gara gara] instead of $\rightarrow$ [gArA gArA]. So that, this word was pronounced like Bahasa Indonesia word rather than like Basa Osing.

"Bonekané dikèkena ning anaké, terus keluargané iku seneng." (RS, 17)

RS (17) also pronounced the word keluarga 'family' with [keluwarga] instead of $\rightarrow$ [keluwargA]. Not only that, almost all of the participants in this group pronounced mobil 'car' with [mObil] instead of $\rightarrow$ [mObIl].

3. As explained earlier, in Basa Osing, some consonants are palatalized. However, many participants also ignored this when retelling silent movie or picture. The consonants that should be palatalized found in data are $/ \mathrm{b} /, / \mathrm{g} /, / \mathrm{m} /, / \mathrm{D} /$, $/ \mathrm{d} /$.

Sample for $/ \mathrm{b} /$ :

"Terus wong iku nggak gelem dibayar" (RS, 17)

"...uwong ning pasar, tawa-tawaan, dodolan, sembarang wis,..” (LD, 24)

Sample for / $\mathrm{g} /$ :

"Dadi iku gambaré ning, nong, pasar blambangan" (RA, 23)

Sample for $/ \mathrm{m} /$ :

"Sampek ning umyahe si hang numpak kendaraan motor mau byalek ning omahé ketemu bojoné ambi anaké" (WR, 53)

Sample for /D/:

"Ning tengah dyalan, nemoni kendaraan mogok." (WR, 53) 


\section{Sample for /d/:}

"Mari ngono, nang dalan, ana keluarga hang numpak. motor" (RA, 23)

The examples above that are marked in bold are examples of words that the consonant $/ \mathrm{b} /, \mathrm{g} /$, $/ \mathrm{m} /, / \mathrm{D} /, / \mathrm{d} /$ are not palatalized. The correct words should be pronounced like this.

$$
\begin{aligned}
& \text { Dibayar } \rightarrow \text { [dib }{ }^{\mathrm{y}} \text { ayar] } \\
& \text { Sembarang } \rightarrow \text { [semb } b^{\mathrm{y}} \text { aran] } \\
& \text { Gambar } \rightarrow\left[\mathrm{g}^{\mathrm{y}} \mathrm{amb}^{\mathrm{y}} \mathrm{ar}\right] \\
& \text { Omah } \rightarrow \text { [umªh] } \\
& \text { Kendaraan } \left.\rightarrow \text { [kenD }^{\mathrm{y}} \text { araan }\right] \\
& \text { Dalan } \rightarrow \text { [d }{ }^{\mathrm{y}} \text { alan] }
\end{aligned}
$$

However, the participants also showed several words that were correctly pronounced. It happens because a palatalized consonant is an allophone that does not distinguish meaning if it is not used. However, by palatalizing the consonant it will show an accent that is more "Osing" than similar to Javanese. Here are some words that are correctly pronounced by some participants.

"isun ndeleng ana uwong kelambi abyang" (RS, 17) "akeh uwong-uwong hang pada tuku tuku kebutuhané nang umyah." (Z, 18)

"man ana bapak-bapak byalek teka kerja" (L, 24) "umahisun alamaté ning jalan bromo nomer limo, Singotrunan, Byanyuwangi" (WR, 53)

"Hun pikir gedigu byaen weh." (WR, 53)

"Lha ning tengah dyalan, kecaruk karo uwong liyo" (L, 24)

"Anaké digyendhong ambi dijunutna badiah hang diunèni ambi lare cilik" (WR, 53)

4. Besides some consonants have to be palatalized, the difference between the Javanese language and Basa Osing is in the vocal /i/ and /u/ being diphthongized if it is at the end of the word. Therefore, vocal /i/ becomes [ai] and / $\mathrm{u} /$ becomes [au]. However, many participants ignore this, especially in prepositions $\mathbf{i} \boldsymbol{k} \boldsymbol{i}^{\prime}$ 'this' [ikai] and $\mathbf{i} \boldsymbol{k} \boldsymbol{u}$ 'that' [ikau]. Those words seem very prominent, because participants use the word repeatedly remembering those words are preposition. Another words that should be diphthongized on vocal / i/ and / $\mathrm{u} /$ is.

"Akeh unvong sing dodolan buab-buahan, terus klambi-klambi” (B, 28)

"...bromo nomer limo, Singotrunan, Byanyuwangi” (WR, 53)

The word $\mathbf{k l a m b i}$ 'clothes' should be pronounced [klambai] and Banyuwangi should be pronounced [banuwayai]. However, again, because [ai] and [au] are only variations of phoneme $/ \mathrm{i} /$ and $/ \mathrm{u} /$, then it does not change the meaning of the word, but less like native speaker of Basa Osing. But, not all participants ignore this, for example:

"Dadi ana uwong hang tukau, ana uwong hang dodol" (WR, 53)

The word [tukau] is derived from the word [tuku] 'buy' which is the vowel $/ \mathrm{u} /$ at the end of the word being extracted to [au].

\section{CONCLUSION}

Based on their behavior characteristics, all the participants did some errors. In form of pronunciation, the participants ignored the diphtongization of vocals /i/ and $/ \mathrm{u} /$ at the end of the word and the palatalization of $/ \mathrm{b} /$ at the beginning and at the middle of the word, /d/ at the middle of the word, /D/ at the middle of the word, $/ \mathrm{g} /$ at the beginning and middle of the word, and $/ \mathrm{m} /$ in the middle of the word, so that the spoken word sounds more like a word in Javanese than Basa Osing.

\section{REFERENCES}

[1] Arps, B. 2010. Geliat Bahasa Selaras Zaman Perubahan Bahasa-bahasa di Indonesia Pasca-Order Baru. Research Institute for Languages and Cultures of Asia and Africa (ILCAA): Tokyo University of Foreign Studies.

[2] Pemerintah Provinsi Jawa Timur. 2014. Peraturan Gubernur Jawa Timur Nomor 19 Tahun 2014 Tentang Mata Pelajaran Bahasa Daerah Sebagai 
Muatan Lokal Wajib di Sekolah/Madrasah. Surabaya: Pemprov Jatim.

[3] Wedhawati. 2006. Tata Bahasa Jawa Mutakhir (Edisi Revisi). Yogyakarta: Kanisius.

[4]Jusuf, A. \& Noor, H. N. 2016. Isun Dhemen Basa Using 2. Banyuwangi: Sengker Kuwung

[5] Kridalaksana, H. 2008. Kamus Linguistik. Jakarta: Gramedia Pustaka Utama.

[6] Ramadani et al. 2017. The Language Attitude of Balinese on The Second Generation Immigrant's Parents in Kampung Bali Langkat, North Sumatera. International Journal of Language Learning and Applied Linguistics World, Vol. 15, No. 2, p. 23-32.

[7] Gusnawaty et al. 2017. Sikap Bahasa Keluarga Kawin Campur Antar Etnik Di Kabupaten Maros: Pendekatan Sosiolinguistik. Prosiding Seminar Antarabangsa. Arkeologi, Sejarah Bahasa Dan Budaya. Di Alam Melayu (ASBAM) ke-6. Johor bahru, 12-13 August 2017.

[8] Purwo, B. K., \& Sukamto, K. 2014. Mother Language of Indonesian Children: A Snapshot of Maintenance of Javanese in Gunung Kidul. Prosiding Kongres Internasional Masyarakat Linguistik Indonesia, Bandar Lampung: Pebruary, 19-22, 2014. p. 8-11. 